\title{
Karakteristik dan Efektivitas Salep Madu Klanceng dari Lebah Trigona sp. sebagai Antibakteri dan Penyembuh Luka Sayat
}

\section{Characteristic and Effectivity of Klanceng Honey Ointment from Trigona sp. as an Antibacteria and Wound Healer}

\author{
Martin Aristo Cahyadi ${ }^{1}$, B. Boy Rahardjo Sidharta ${ }^{1 *}$, Nelsiani To'bungan ${ }^{1}$ \\ ${ }^{1}$ Program Studi Biologi Fakultas Teknobiologi Universitas Atma Jaya Yogyakarta, Jalan Babarsari No. 44 \\ Yogyakarta 55281 \\ E-mail: boy.sidharta@uajy.ac.id \\ *Penulis Korespondensi
}

\begin{abstract}
Continuous use of antibiotics causes resistance to bacteria. One of the natural ingredients that can be an alternative treatment is Klanceng honey. This study aimed to determine the optimal preparation of Klanceng honey ointment and its effect on wound healing and bacterial infections. The stages of this study consisted of honey phytochemical test, ointment preparation, ointment test, bacterial purity test, drag zone test, and bioassay test on rabbit. Klanceng honey which was tested contained alkaloid compounds. Variations of honey ointment made were 1:1, 1:2, 1:5, and 5:1. The result of the ointment was semi-solid, yellow, with $\mathrm{pH} 4.8$, not homogeneous yet, having a sticking power of about 265.4 seconds, and a power of spread of $1.76 \mathrm{~cm}$. Honey ointment was capable of inhibiting Staphyococcus aureus and Pseudomonas aeruginosa with a diameter of $1.2 \mathrm{~mm}$. This honey ointment also gives wound healing effect up to $0.3 \mathrm{~cm}$.
\end{abstract}

Keywords: ointment, klanceng honey, antimicrobial, wound healing

\begin{abstract}
Abstrak
Penggunaan antibiotik secara terus menerus dapat menimbulkan resistensi pada bakteri. Salah satu bahan alami yang dapat menjadi alternatif pengobatan adalah madu klanceng. Penelitian ini bertujuan untuk mengetahui sediaan salep madu klanceng yang optimal dan efeknya terhadap penyembuhan luka dan infeksi yang disebabkan oleh bakteri. Tahapan penelitian ini terdiri dari uji fitokimia madu, pembuatan salep, uji sediaan salep, uji kemurnian bakteri, uji zona hambat, dan uji bioassay pada kelinci. Madu klanceng yang diuji mengandung senyawa alkaloid. Variasi salep madu dibuat dengan perbandingan basis salep dan madu adalah 1:1, 1:2, 1:5, dan 5:1. Hasil salep berbentuk semi padat, berwarna kuning, pH sekitar 4,8, belum homogen, memiliki daya lekat sekitar 265,4 detik, dan daya sebar sebesar $1,76 \mathrm{~cm}$. Salep madu mampu menghambat bakteri $S$. aureus dan $P$. aeruginosa dengan diameter sebesar $1,2 \mathrm{~mm}$. Salep madu ini juga memberikan efek menyembuhkan luka hingga $0,3 \mathrm{~cm}$.
\end{abstract}

Kata kunci: salep, madu klanceng, antimikrobia, penyembuhan, luka sayat

Diterima: 4 Juli 2019, disetujui: 16 Agustus 2019

\section{Pendahuluan}

Pengobatan untuk penyembuhan luka khususnya luka terbuka atau yang terinfeksi bakteri sering menggunakan antibiotik, karena dapat membunuh mikrobia dengan cepat. Penggunaan antibiotik terus menerus dapat menimbulkan resistensi pada bakteri (Morita dkk., 2014). Resistensi antibiotik yang terjadi pada mikrobia memunculkan kekhawatiran untuk menggunakan antibiotik sebagai obat penyembuhan luka. Bahan alami dapat menjadi alternatif untuk menyembuhkan luka. Madu merupakan salah satu bahan alami yang dapat digunakan untuk penyembuhan luka karena memiliki manfaat sebagai antimikrobia dan antiinflamasi.

Salah satu jenis madu yang dapat dimanfaatkan adalah madu klanceng. Keunggulan madu klanceng dibandingkan 
dengan madu yang lain berdasarkan penelitian Garedew dkk. (2003) yaitu madu klanceng terbukti memiliki efek antimikrobia yang lebih kuat karena mengandung hidrogen peroksida, fenol, dan flavonoid. Madu dapat dicampur menjadi sediaan salep sehingga tidak menyebar kemana-mana, tahan lama, stabil, dan memberikan efek yang maksimal. Penelitian ini bertujuan untuk mengetahui stabilitas dan efektivitas salep madu klanceng dalam menghambat Staphyococcus aureus dan Pseudomonas aeruginosa serta efek penyembuhan luka sayat pada hewan uji.

\section{Metode Penelitian}

Madu klanceng diperoleh dari peternak di Gunung Kidul, kelinci yang digunakan adalah kelinci albino jantan yang berasal dari peternak di Moyudan, dan sediaan $S$. aureus dan $P$. aeruginosa diperoleh dari Laboratorium Teknobio-Industri Fakultas Teknobiologi Universitas Atma Jaya
Yogyakarta. Basis salep yang digunakan adalah vaselin putih, yang merupakan basis salep hidrokarbon (bebas air) dan carboxymethyl cellulose (CMC) sebagai pengental. Kedua bahan termasuk kategori cosmetic grade (Husnani dan Muazam, 2017). Tahapan penelitian yang dilakukan meliputi uji fitokimia madu, pembuatan salep madu klanceng, uji sediaan salep (uji organoleptik, homogenitas, $\mathrm{pH}$, daya sebar, dan daya lekat), uji zona hambat, dan pengujian pada kelinci (pembuatan luka sepanjang $1 \mathrm{~cm}$ dan pemberian salep).

\section{Hasil dan Pembahasan}

\section{Fitokimia Madu Klanceng}

Uji fitokimia madu klanceng berfungsi untuk mengetahui senyawa kimia yang terkandung dalam madu klanceng. Berdasarkan uji fitokimia yang sudah dilakukan, hasil dapat dilihat pada Tabel 1.

Tabel 1. Hasil Uji Fitokimia Madu Klanceng

\begin{tabular}{cc}
\hline Jenis Fitokimia yang Diuji & Hasil \\
\hline \hline Alkaloid (Uji Meyer) & + \\
Alkaloid (Uji Wagner) & - \\
Alkaloid (Dragendorff) & - \\
Terpenoid & - \\
Steroid & - \\
Saponin & - \\
Tanin & - \\
Flavonoid I & - \\
Flavonoid II & - \\
\hline \hline
\end{tabular}

Keterangan: + : memperlihatkan hasil uji positif, - : memperlihatkan hasil uji negatif

Hasil uji fitokimia menunjukkan bahwa madu klanceng mengandung senyawa alkaloid yang ditunjukkan oleh hasil positif pada uji alkaloid dengan reagen Wagner dan Meyer. Hasil yang diperoleh berbeda dengan penelitian Garedew dkk. (2013) dan Jalil dkk. (2017) yang menyatakan bahwa madu klanceng mengandung senyawa flavonoid. Jika hasil dibandingkan dengan penelitian Thamrin dkk. (2016), maka hasil uji fitokimia tidak berbeda.

Perbedaan hasil uji dapat disebabkan oleh pengaruh sumber makanan lebah terhadap kandungan senyawa dalam madu. Menurut
Pacini dan Nicolson (2007), umumnya nektar bunga mengandung ion $\mathrm{K}$, asam askorbat, fenol, lipid, dan alkaloid. Perbedaan hasil uji fitokimia penelitian ini dengan penelitian lain bisa terjadi dikarenakan sumber makanan yang berbeda.

\section{Uji Sediaan Salep}

Salep madu klanceng dibuat sebanyak 30 gram dengan formulasi perbandingan basis salep : madu sebesar 1:1, 1:2, 1:5, dan 5:1. Hasil uji yang diperoleh dapat dilihat pada Tabel 2. 
Tabel 2. Hasil Uji Sediaan Salep Madu Klanceng

\begin{tabular}{ccccc}
\hline \hline \multirow{2}{*}{ Parameter } & \multicolumn{4}{c}{ Variasi Konsentrasi Salep } \\
\cline { 2 - 5 } & $\mathbf{1 : 1}$ & $\mathbf{1 : 2}$ & $\mathbf{1 : 5}$ & $\mathbf{5 : 1}$ \\
\hline \hline Bentuk & Semi padat & Semi padat & Semi padat & Semi padat \\
Warna & Kuning & Kuning & Kuning & Putih kekuningan \\
Bau & ++ & ++ & +++ & + \\
pH & 4,92 & 4,65 & 4,8 & 5,3 \\
Homogenitas & Belum homogen & Belum homogen & Belum homogen & Belum homogen \\
\hline \hline
\end{tabular}

Keterangan: + : sedikit berbau madu, ++ : berbau madu, +++ : khas madu (kuat)

Keempat formulasi salep memiliki $\mathrm{pH}$ yang aman bagi kulit sesuai dengan penelitian Sinambela dkk. (2013) yang mengatakan sediaan salep yang baik memiliki $\mathrm{pH}$ sekitar 4,5-6,5 dan memenuhi syarat $\mathrm{pH}$ menurut SNI 16-4399-1996 yaitu 4,5-8,0 untuk sediaan topikal. Namun, keempat formulasi salep belum homogen karena masih terdapat butiran CMC yang belum larut. Ketidakhomogenan sediaan akan berpengaruh pada efektifitas dan penerimaan oleh konsumen (Lestari dkk.,
2017). Waktu pemanasan dalam proses pembuatan salep menyebabkan menguapnya kandungan air dalam madu sehingga hanya sebagian CMC yang dapat mengikat air dalam madu (Anggraini dkk., 2016).

Uji daya lekat bertujuan untuk mengetahui lama waktu yang diperlukan salep melekat pada kulit sedangkan uji daya sebar bertujuan untuk mengetahui kemampuan salep untuk menyebar jika diaplikasikan ke kulit. Hasil uji dapat dilihat pada Tabel 3 dan 4.

Tabel 3. Daya Lekat Salep Madu Klanceng

\begin{tabular}{cc}
\hline Konsentrasi Salep & Rerata Daya Lekat (detik) \\
\hline \hline $5: 1$ & $33,8^{\mathrm{a}}$ \\
$1: 2$ & $84,2^{\mathrm{a}, \mathrm{b}}$ \\
$1: 1$ & $127,2^{\mathrm{b}}$ \\
$1: 5$ & $265,4^{\mathrm{c}}$ \\
\hline \hline
\end{tabular}

$\overline{\text { Keterangan: Rerata yang diikuti huruf yang sama menunjukkan tidak ada beda nyata secara statistik dengan }}$ $P<0,05$.

Syarat daya lekat salep yang baik adalah tidak kurang dari 4 detik (Lestari dkk., 2017). Jadi, keempat formulasi salep telah memenuhi syarat daya lekat salep yang dikemukakan oleh Lestari dkk. (2017). Waktu lekat salep ini memengaruhi lama waktu kontak salep dengan kulit karena waktu kontak yang lebih lama akan memberikan waktu lebih lama bagi tubuh untuk menyerap senyawa yang dibawa oleh salep (Ulaen dkk., 2012).

Tabel 4. Daya Sebar Salep Madu Klanceng

\begin{tabular}{cc}
\hline Konsentrasi Salep & Rerata Daya Sebar $(\mathbf{c m})$ \\
\hline \hline $5: 1$ & $1,5^{\mathrm{a}}$ \\
$1: 2$ & $1,66^{\mathrm{a}, \mathrm{b}}$ \\
$1: 1$ & $1,74^{\mathrm{b}}$ \\
$1: 5$ & $1,76^{\mathrm{b}}$ \\
\hline \hline
\end{tabular}

$\overline{\text { Keterangan: Rerata yang diikuti huruf yang sama menunjukkan tidak ada beda nyata secara statistik dengan }}$ $P<0,05$.

Menurut Lestari dkk. (2017), daya sebar salep yang baik adalah 5-7 cm. Jadi, keempat salep belum memenuhi syarat daya sebar. Hal ini mungkin disebabkan oleh kepadatan salep yang membuat salep tidak mudah mengalir sehingga diameter penyebarannya tidak semakin luas (Husnani dan Muazham, 2017).

\section{Uji Zona Hambat}

Uji zona hambat bertujuan untuk mengetahui aktivitas antimikrobia dari salep madu klanceng. Metode zona hambat yang digunakan yaitu metode Kirby Bauer/paper disc. Hasil zona hambat pada $S$. aureus dan $P$. aeruginosa dapat dilihat pada Tabel 5 . 
Tabel 5. Diameter Zona Hambat (mm) terhadap kedua mikrobia uji

\begin{tabular}{ccc}
\hline \hline Konsentrasi Salep & Staphyococcus aureus & Pseudomonas aeruginosa \\
\hline \hline $1: 5$ & $0^{\mathrm{a}}$ & $0,6^{\mathrm{a}}$ \\
$1: 1$ & $0,8^{\mathrm{a}}$ & $0,6^{\mathrm{a}}$ \\
$1: 2$ & $0,8^{\mathrm{a}}$ & $0,8^{\mathrm{a}}$ \\
$5: 1$ & $1^{\mathrm{a}}$ & $1,2^{\mathrm{a}}$ \\
Kontrol (Kalmicetine) & $4,2^{\mathrm{b}}$ & $5,4^{\mathrm{b}}$ \\
\hline \hline
\end{tabular}

Keterangan: rerata yang diikuti huruf yang sama pada kolom yang sama menunjukkan tidak ada beda nyata secara statistik dengan $P<0,05$.

Berdasarkan Tabel 5, zona hambat yang terbentuk tidak sebesar atau tidak setara dengan kontrol. Menurut Davis dan Stout (1971), aktivitas antimikrobia dikatakan lemah jika diameter zona hambat yang kurang dari 5 $\mathrm{mm}$. Aktivitas antimikrobia digolongkan dalam kategori sedang jika zona hambatnya 5-10 mm, digolongkan kuat jika zona hambatnya 10-20 $\mathrm{mm}$, dan digolongkan sangat kuat jika zona hambat berdiameter lebih dari $20 \mathrm{~mm}$.

Zona hambat yang dihasilkan salep madu klanceng tidak lebih dari $5 \mathrm{~mm}$ sehingga aktivitas antimikrobia salep madu klanceng dapat digolongkan dalam kategori lemah sehingga belum efektif dalam menghambat $S$. aureus dan $P$. aeruginosa.

Faktor yang memengaruhi hasil zona hambat adalah pengaruh pemanasan (suhu $70^{\circ} \mathrm{C}$ selama 30 menit) saat pembuatan salep. Pemanasan saat pembuatan salep memengaruhi senyawa dalam madu.
Menurut Bogdanov dkk. (2014), pemanasan madu seharusnya seminimal mungkin karena waktu pemanasan yang berlebihan dapat merusak senyawa pada madu. Enzim dan senyawa seperti alkaloid yang rusak karena panas tidak dapat berfungsi sebagai antibakteri.

\section{Uji Bioassay}

Hewan uji yang digunakan adalah kelinci albino jantan berumur 2 bulan dan berat 1,5 kg. Sebelum luka dibuat, rambut kelinci dicukur di enam area pada punggung kelinci dengan luas masing-masing sekitar $2 \times 2 \mathrm{~cm}^{2}$. Kelinci dibius dengan eter untuk meminimalisir rasa sakit ketika disayat menggunakan silet steril. Pengamatan dilakukan selama tujuh hari dan pemberian salep madu dilakukan setiap hari. Hasil pengamatan dapat dilihat pada Gambar 1 dan Tabel 6.

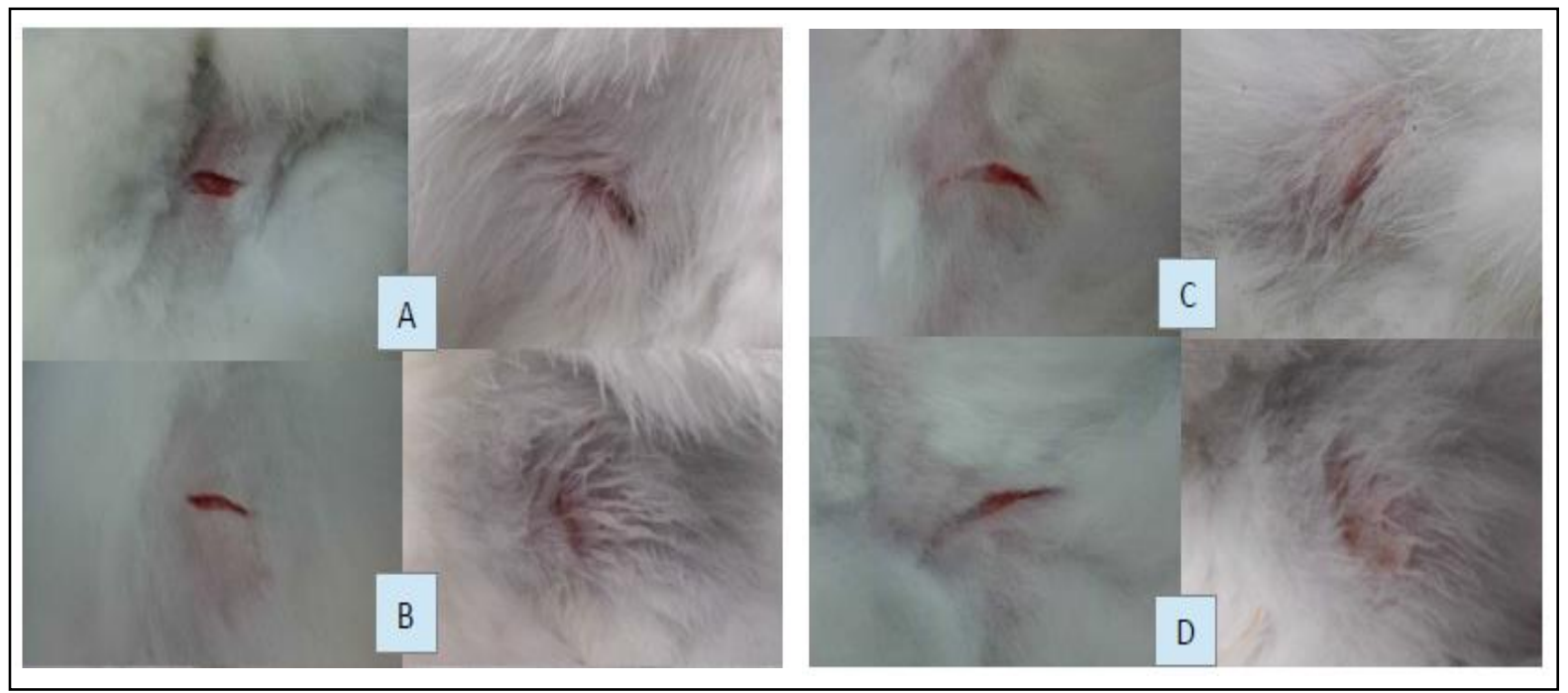

Gambar 1. Kondisi luka hari ke-1 dan hari ke-7 pada kelinci. A = Perlakuan Salep 1:1, B = Perlakuan Salep 1:2, C = Perlakuan Salep 1:5, dan D = Perlakuan Salep 5:1. 
Tabel 6. Penyusutan Panjang Luka pada Kelinci

\begin{tabular}{ccccccc}
\hline \hline \multirow{2}{*}{ Hari } & \multicolumn{7}{c}{ Panjang Luka (cm) } \\
\cline { 2 - 7 } & Salep 1:1 & Salep 1:2 & Salep 1:5 & Salep 5:1 & K+ & K- \\
\hline \hline 1 & 0,93 & 0,67 & 1 & 0,8 & 0,65 & 0,85 \\
2 & 0,93 & 0,67 & 1 & 0,8 & 0,65 & 0,85 \\
3 & 0,8 & 0,63 & 0,96 & 0,8 & 0,65 & 0,85 \\
4 & 0,76 & 0,6 & 0,96 & 0,73 & 0,55 & 0,85 \\
5 & 0,76 & 0,56 & 0,93 & 0,7 & 0,55 & 0,85 \\
6 & 0,73 & 0,53 & 0,76 & 0,7 & 0,5 & 0,85 \\
7 & 0,63 & 0,46 & 0,73 & 0,67 & 0,5 & 0,8 \\
\hline \hline Selisih & 0,3 & 0,21 & 0,27 & 0,13 & 0,15 & 0,05 \\
\hline \hline
\end{tabular}

Keterangan: K+: Kontrol positif, K-: Kontrol negatif

Penyusutan panjang dilihat dari selisih panjang luka di hari pertama dikurangi hari ketujuh. Jika dibandingkan dengan kontrol, maka perlakuan salep 1:1, 1:2, dan 1:5 memberikan efek penyembuhan yang lebih baik sedangkan salep 5:1 belum memberikan efek yang setara dengan salep kontrol.

Faktor stres pada kelinci dapat berpengaruh dalam penyembuhan luka. Luka sayat memberi rasa nyeri pada kelinci yang menimbulkan respon stres metabolik (Devor, 1996). Kadar beta endorfin yang dilepas oleh pituitari akan meningkat sehingga menekan aktivitas makrofag. Aktivitas makrofag seperti pelepasan sitokin akan menurun. Faktor fibroblast growth factor (FGF) dan vascular endothelial growth factor (VEGF) yang berperan dalam pembentukan pembuluh darah juga terhambat perannya sehingga penyembuhan luka menjadi lebih lama (Devor, 1996).

Penyembuhan luka juga didukung dengan sediaan salep yang dibuat. Jenis sediaan salep memberikan kondisi tertutup pada luka sehingga mencegah adanya infeksi. Sediaan salep juga dapat meningkatkan hidrasi pada kulit atau menjaga molekul air pada kulit tidak menguap sehingga penyerapan senyawa aktif pada salep lebih baik (Joenoes, 1998).

\section{Simpulan dan Saran}

\section{Simpulan}

Karakteristik salep semi padat, berwarna kuning, berbau madu, $\mathrm{pH}$ 4,65-5,3, daya lekat $33,8-265,4$ detik, daya sebar $1,5-1,76 \mathrm{~cm}$, sifat fisik belum homogen, dan aktivitas antibakteri salep madu klanceng tergolong dalam kategori lemah sehingga belum efektif dalam menghambat $P$. aeruginosa dan $S$. aureus.
Salep madu klanceng memiliki efek penyembuhan luka hingga $0,3 \mathrm{~cm}$ dan efek antiinflamasi karena tidak terjadi pembengkakan pada daerah luka.

\section{Saran}

Proses pembuatan salep saat pemanasan dengan suhu $70^{\circ} \mathrm{C}$ dan komposisi salep perlu diperhatikan agar salep yang dihasilkan lebih homogen dan tidak merusak senyawa dalam madu. Kepadatan salep juga perlu diperbaiki melalui penambahan adeps lanae atau cara pengadukan secara terus menerus sehingga daya sebar salep dapat ditingkatkan.

\section{Daftar Pustaka}

Anggraini, D., Radiati, L., dan Purwadi. 2016. Penambahan carboxymethyle cellulose (CMC) pada minuman madu sari apel ditinjau dari rasa, aroma, warna, $\mathrm{pH}$, viskositas, dan kekeruhan. Jurnal Ilmu dan Teknologi Hasil Ternak 11(1): 59-68.

Bogdanov, S., Ruofi, K., dan Oddo, L. 2004. Physicochemical methods for the characterisation of unifloral honeys: a review. Apidologie 35: 417.

Davis, W. dan Stout, T. 1971. Disc plate method of microbiological antibiotic. Applied Microbiology 22(4): 659-665.

Devor, M. 1996. Pain Mechanism and Pain Syndrome. IASP Press, Seattle.

Garedew, A., Schmolz, E., dan Lamprecht, I. 2003. The antimicrobial activity of honey of the stingless bee Trigona spp. Journal of Apicultural Science 47(1): 37-48.

Husnani dan Muazham, F. 2017. Optimasi parameter fisik viskositas, daya sebar, dan daya lekat pada basis natrium cmc dan carbopol 940 pada gel madu dengan metode simplex lattice design. Jurnal Ilmu Farmasi 14(1): 11-17.

Jalil, M., Kasmuri, A., dan Hadi, H. 2017. Stingless bee honey, the natural wound healer: a review. Skin 
Pharmacology and Physiology 30: 66-75.

Joenoes, N. 1998. Ars Prescribing: Resep yang Rasional. Airlangga University Press, Surabaya. Halaman 121-129.

Lestari, T., Yunianto, B., dan Winarso, A. 2017. Evaluasi mutu salep dengan bahan aktif temugiring, kencur, dan kunyit. Jurnal Kebidanan dan Kesehatan Tradisional 2(1): 1-59.

Morita, Y., Tomida, J., dan Kawamura, Y. 2014. Responses of Pseudomonas aeruginosa to antimicrobials. Frontiers in Microbiology 4: 1-8.

Pacini, E. dan Nicolson, S. 2007. Nectaries and Nectar. Springer, New York. Halaman 1-18.

Sinambela, H., Pratiwi, L., dan Sari, R. 2013. Optimasi formulasi sediaan salep minyak ikan gabus
(Channa striata Bloch) sebagai obat luka sayat dengan metode simplex lattice design. Jurnal Untan 10(1): 1-16.

Standar Nasional Indonesia (SNI 16-4399-1996). 1996. Sediaan Tabir Surya. Badan Standarisasi Nasional, Jakarta.

Thamrin, A., Erwin, dan Syafrizal. 2016. Uji fitokimia, toksisitas serta antioksidan ekstrak propolis pembungkus madu lebah Trigona incisa dengan metode 2,2-diphenyl-1-picrylhidrazyl (DPPH). Jurnal Kimia Mulawarman 14(1): 54-60.

Ulaen, S., Banne, Y., dan Suatan, R. 2012. Pembuatan salep antijerawat dari ekstrak rimpang temulawak (Curcuma xanthorrhiza Roxb.). Jurnal Ilmiah Farmasi 3(2): 45-49. 